\title{
Artikel
}

\section{Mensenhandel, uitbuiting en de Hoge Raad: een overzicht en waardering}

Mr. dr. L.B. (Luuk) Esser*

\section{NTS 2020/5}

\section{Inleiding}

De strafbaarstelling van mensenhandel in artikel $273 \mathrm{f} \mathrm{Sr}$ houdt de gemoederen intussen alweer even bezig. De kwalificaties die aan dit langste artikel uit het Wetboek van Strafrecht worden gegeven liegen er niet om. Klip noemde het eerder al een 'wetstechnisch gedrocht'. Lestrade zette de bepaling recent nog weg als 'misbaksel'. ${ }^{2}$ Wie de tekst van de wet enige tijd op zich laat inwerken, merkt Reijntjes op, wordt door verwarring bevangen. ${ }^{3}$

Het is niet moeilijk om te achterhalen wat de bron van de onvrede is: in artikel $273 \mathrm{f} \mathrm{Sr}$ zijn negen uiteenlopende gedragingen strafbaar gesteld die tegelijkertijd wel van dezelfde delictskwalificatie zijn voorzien - 'mensenhandel' - en met dezelfde zware straf worden bedreigd (maximaal twaalf jaar gevangenisstraf voor ongekwalifi-

Mr. dr. L.B. Esser is universitair docent straf- en strafprocesrecht aan het Instituut voor Strafrecht \& Criminologie van de Faculteit der Rechtsgeleerdheid van de Universiteit Leiden en rechter-plaatsvervanger in de Rechtbank Rotterdam. De auteur dankt mr. S.R. Bakker, prof. mr. dr. C.P.M. Cleiren, prof. mr. dr. P.M. Schuyt en prof. mr. dr. J.M. ten Voorde voor hun waardevolle opmerkingen op een eerdere versie van dit artikel.

1. A.H. Klip, annotatie bij HR 10 september 2013, ECLI:NL:HR:2013:670, NJ 2015/443

2. S.M.A. Lestrade, annotatie bij HR 16 oktober 2018, ECLI:NL:HR: 2018:1941, SR Updates 2018-0397.

3. J.M. Reijntjes, annotatie bij HR 19 maart 2019, ECLI:NL:HR:2019:383, NJ 2019/207. ceerde mensenhandel). Het is bovendien maar de vraag of met die gedragingen steeds het rechtsbelang van de persoonlijke vrijheid beschermd is, een veronderstelling die wel besloten ligt in de opneming van de gedragingen in de titel met misdrijven tegen de persoonlijke vrijheid. De deels internationale, deels nationale achtergrond van het wetsartikel maken tegelijkertijd dat de wetshistorie niet eenvoudig te begrijpen en duiden is.

De Hoge Raad is in de afgelopen jaren in toenemende mate een stempel gaan drukken op het mensenhandelartikel. De arresten die hij recent heeft gewezen hebben geleid tot een flinke inperking van de strafrechtelijke aansprakelijkheid die op grond van artikel $273 \mathrm{f} \mathrm{Sr}$ kan worden gevestigd. De voornaamste techniek die hij daarbij heeft gehanteerd, is het inlezen van een buitenwettelijk bestanddeel 'uitbuiting', dat - in de bewoordingen van de Hoge Raad zelf - doorgaat als 'impliciet bestanddeel'. De vraag die daardoor automatisch rijst, is hoe deze vorm van rechtsvorming zich verhoudt tot de taak van de strafwetgever.

In deze bijdrage wordt gepoogd twee vragen te beantwoorden. Allereerst wordt bezien wat precies de implicaties zijn van het inlezen van het uitbuitingsbestanddeel in sommige subleden van artikel $273 \mathrm{f}$ lid $1 \mathrm{Sr}$. Ten tweede wordt beoogd om een begin van een antwoord te verschaffen op de vraag of de ontstane takkerdeling die tussen wetgever en Hoge Raad - een wenselijke is: wat kan daarover worden gezegd in het licht van de machtenscheiding? Om die vraag op een goede manier te belichten, wordt bij de bespreking van de arresten ook wat langer stilgestaan bij de totstandkomingsgeschiedenis van de verschillende subleden. Daardoor is een beter begrip van de arresten mogelijk, en de argumenten die aan het inlezen van het bestanddeel 'uitbuiting' ten grondslag zijn gelegd. 
Voor de beantwoording van de opgeworpen vragen is het in eerste instantie van belang om een beknopte weergave te geven van de strafbaarstelling van mensenhandel in het algemeen (par. 2). Vervolgens wordt in paragraaf 3 de focus verlegd naar de relevante rechtspraak van de Hoge Raad. Uitgelicht zijn de arresten ten aanzien van een drietal, qua aard en inhoud te onderscheiden gedragingen in het eerste lid van artikel $273 \mathrm{f} \mathrm{Sr}$, waarin de Hoge Raad recentelijk het bestanddeel 'uitbuiting' heeft ingelezen. Bezien zal worden welke argumenten hij daarbij heeft gebruikt en hoe de uitleg zich verhoudt tot de totstandkomingsgeschiedenis van deze bepalingen. In de tussenconclusie in paragraaf 4 wordt antwoord gegeven op de eerste vraag. De tweede, meer normatieve vraag - die naar de rechtszekerheid en de tot stand gekomen 'werklastverdeling' tussen wetgever en rechter - wordt behandeld in paragraaf 5 . In paragraaf 6 wordt afgesloten met een korte conclusie.

\section{De strafbaarstelling van mensenhandel}

Zoals net al even aangestipt, is in artikel $273 \mathrm{f} \mathrm{Sr}$ niet één, maar zijn in totaal negen gedragingen als mensenhandel gekwalificeerd. Een introductie op hoofdlijnen laat zich nog het beste begeleiden door de negen delicten op te delen in drie groepen: (i) de formeel omschreven gedragingen uit de subleden 1 tot en met 3, (ii) de uitbuitingsgedragingen in de subleden 4 en 5 en (iii) de profijttrekkersgedragingen uit de subleden 6 tot en met 9. ${ }^{4}$ Typisch aan de gedragingen in de eerste groep is dat ze alle formeel omschreven zijn, wat duidelijk te zien is aan de opneming van het (subjectieve) oogmerkbestanddeel. Waarop dit oogmerk van de dader zich moet richten, loopt uiteen. Bij sublid 3 gaat het zakelijk gezegd om handelingen gericht op de temerkstelling van een prostitué/prostituee in het buitenland. Bij de subleden 1 en 2, waarvan de bewoordingen hun oorsprong vinden in het Mensenhandelprotocol van de Verenigde Naties (2000), ${ }^{5}$ dient te worden bewezen dat het handelen van de verdachte gericht was op iemands uitbuiting. ${ }^{6} \mathrm{Om}$ het oogmerk van uitbuiting vast te stellen, zo heeft de Hoge Raad in zijn Chinese horeca-arrest uit 2009 al geoor-

4. Zie voor een alternatieve indeling onder meer S.M.A. Lestrade, De strafbaarstelling van arbeidsuitbuiting in Nederland (diss. Nijmegen), Deventer: Wolters Kluwer 2018, p. 73-127.

5. Vgl. art. 3, onder a, VN-Protocol inzake de voorkoming, bestrijding en bestraffing van mensenhandel, in het bijzonder vrouwenhandel en kinderhandel, tot aanvulling van het Verdrag van de Verenigde Naties tegen grensoverschrijdende georganiseerde misdaad (New York, 15 november 2000), Trb. 2001, 69 en Trb. 2004, 35.

6. Of op de verwijdering van iemands organen. Deze laatste vorm van mensenhandel wordt in deze bijdrage verder niet besproken. In Nederland heeft tot dusver nog geen vervolging plaatsgehad voor mensenhandel met het oogmerk van orgaanverwijdering. Wel wordt daarover in empirische zin steeds meer duidelijk. Niet in de laatste plaats hebben de dissertaties van Ambagtsheer en De Jong daaraan bijgedragen. Vgl. F. Ambagtsheer, Organ Trade (diss. Rotterdam), Rotterdam: 2017 en J. de Jong, Human trafficking for the purpose of organ removal (diss. Utrecht), Utrecht: 2017 deeld, dient te worden gekeken naar de aard en duur van de werkzaamheden die voor de verdachte werden verricht, de beperkingen die de tewerkstelling meebracht voor het slachtoffer en het economisch voordeel dat door de tewerksteller is behaald. ${ }^{7}$

De tweede groep delicten bestaat uit de gedragingen die zijn opgenomen in de subleden 4 en 5 . In sublid 4 is zakelijk gezegd strafbaar gesteld degene die een ander door een middel dwingt of beweegt zich voor arbeid of diensten beschikbaar te stellen. ${ }^{8}$ In sublid 5 degene die een minderjarige ertoe brengt zich beschikbaar te stellen voor het verrichten van seksuele handelingen met of voor een derde. ${ }^{9}$ Waar de gedragingen in de subleden 1 en 2 zijn gericht op iemands uitbuiting, heeft de gedraging in sublid 4 volgens de wetgever primair het oog op de uitbuiting zelf. ${ }^{10}$ Deze kwalificatie is daaraan door de minister slechts in de memorie van toelichting gegeven: afgaande op de wettelijke bestanddelen, is 'uitbuiting' bestanddeel noch delictskwalificatie van deze gedraging. ${ }^{11}$ In beginsel volstaat voor het bewijs dan ook dat wordt bewezen dat de ene persoon een andere persoon door een van de in sublid 1 opgenomen middelen heeft gedwongen of bewogen zich voor arbeid of diensten beschikbaar te stellen. In sublid 5 is de systematische specialis van de gedraging uit sublid 4 opgenomen, die uitsluitend ziet op minderjarige slachtoffers. De aanwezigheid van een middel is voor het bewijs van deze gedraging geen vereiste: voldoende is dat wordt bewezen dat een persoon een minderjarige feitelijk tot prostitutiewerkzaamheden heeft gebracht. Zowel voor sublid 4 als 5 geldt dat het gaat om meer materieel omschreven gedragingen; weliswaar is niet vereist dat daadwerkelijk werkzaamheden hebben plaatsgevonden, wel moet vaststaan dat iemand zich daarvoor beschikbaar heeft gesteld.

In de derde groep vinden we de profijttrekkersbepalingen uit de subleden 6 tot en met 9 . In sublid 6 is het opzettelijk voordeeltrekken uit uitbuiting strafbaar gesteld, zonder dat overigens dit begrip 'uitbuiting' nader is gespecificeerd. Deze gedraging heeft eerder in artikel 250a (oud) Sr gestaan en spitste zich toen uitsluitend toe op de profijttrekking uit de gedraging die thans in sublid 4 staat, maar heden ten dage is in de rechtspraak

7. Bij de beoordeling van deze criteria dienen bovendien de in de Nederlandse samenleving geldende maatstaven als referentiekader te worden gehanteerd, zie HR 27 oktober 2009, ECLI:NL:HR:2009:BI7099, NJ 2010/598 m.nt. Y. Buruma, r.o. 2.6.1.

8. In totaal zijn in het eerste sublid, waarnaar sublid 4 verwijst, twaalf middelen opgenomen waarmee personen kunnen worden gedwongen dan wel bewogen. Het gaat onder meer om het gebruik van geweld, de dreiging daarmee, misleiding, misbruik van uit feitelijke omstandigheden voortvloeiend overwicht en misbruik van een kwetsbare positie.

9. Ook hier gaat het om een zakelijke weergave van de gedraging die is strafbaar gesteld.

10. Kamerstukken I/ 2003/04, 29291, 3, p. 18

11. Zie daarover meer uitgebreid L.B. Esser \& C.E. Dettmeijer-Vermeulen, 'Mensenhandel op een tweesprong. De omgang van rechters met de ruim geformuleerde mensenhandelgedraging in de delictsomschrijving van artikel $273 \mathrm{f}$ lid 1 sub 4 Sr', DD 2014/48, afl. 7, p. 512-528. Zie ook S.M.A. Lestrade \& C.R.J.J. Rijken, 'Mensenhandel en uitbuiting nader bepaald', DD 2014/64, afl. 9, p. 664-681. 
ook wel terug te zien dat over de band van sublid 6 het voordeeltrekken uit de gedraging in sublid 1 wordt bewezen. ${ }^{12}$ In sublid 7 is het voordeeltrekken uit orgaanverwijdering gecriminaliseerd, in sublid 8 het trekken van voordeel uit de gedraging die in sublid 5 is strafbaar gesteld. Sublid 9 wijkt in die zin van de subleden 6 tot en met 8 af, dat het bij de daarin opgenomen gedraging gaat om het trekken van voordeel uit een volkomen legale vorm van sekswerk. De middelen die in deze gedraging zijn opgenomen, zijn namelijk - anders dan in de subleden 6 en $7^{13}$ - op de gedmongen bevoordeling uit de opbrengsten van sekswerk gericht, zelfs, juist, als dit sekswerk zelf niet met dwang gepaard ging. Sublid 9 wordt door de wetgever als een specialis van het algemene dwangdelict uit artikel $284 \mathrm{Sr}$ beschouwd. ${ }^{14}$ De gedraging is in 2000 in de wet opgenomen om te voorkomen dat de gedwongen afdracht van inkomsten uit legaal sekswerk buiten het bereik van de strafwet zou blijven.

De opdeling hierboven is nuttig voor het snel kunnen onderscheiden van de gedragingen die in het Wetboek van Strafrecht als mensenhandel zijn strafbaar gesteld. Tegelijkertijd zal hieronder nog blijken dat de arresten van de Hoge Raad aan deze indeling nogal afdoen. En eigenlijk is van een zekere nuancering daarvan ook al sprake door het Chinese horeca-arrest uit 2009. De criteria die daarin zijn opgenomen ter vaststelling van het 'oogmerk van uitbuiting' in de zin van de subleden 1 en 2 doen de blik in strafvorderlijke zin richten op werkzaamheden die al daadwerkelijk hebben plaatsgevonden, hoezeer ook de formele omschrijving van de gedragingen in deze subleden maakt dat voor een bewezenverklaring van zulke werkzaamheden nog geen sprake behoeft te zijn geweest. ${ }^{15}$ In de rechtspraktijk zijn de verschillen tussen de subleden 1 en 4 daarmee niet altijd goed zichtbaar.

12. Zie daarover uitgebreider L.B. Esser, De strafbaarstelling van mensenhandel ontrafeld. Een analyse en waardering in het licht van rechtsbelangen (diss. Leiden), Den Haag: Boom juridisch 2019.

13. Voor het bewijs van sublid 8 behoeven geen middelen te worden bewezen omdat de bepaling zich uitsluitend uitstrekt tot de voordeeltrekking uit door minderjarigen verrichte seksuele handelingen (met of voor een derde tegen betaling).

14. Kamerstukken I/ 1985/86, 18202, 5, p. 8

15. De Chinese horeca-criteria werken, zo zou kunnen worden gezegd, een zekere 'materialisering' van de formeel omschreven delicten in de subleden 1 en 2 in de hand. Het is mijns inziens een schoolvoorbeeld van hoe het formeel strafrecht invloed kan uitoefenen op het materieel strafrecht. Om met Reijntjes te spreken: delictsomschrijvingen kunnen alleen in hun volle betekenis worden doorgrond wanneer zij vanuit hun bewijsbaarheid worden benaderd. J.M. Reijntjes, 'Het aantonen van opzet. Over de verhouding tussen vorm en materie in het strafrecht', in: M.S. Groenhuijsen \& J.B.H.M. Simmelink (red.), Glijdende Schalen (De Hullu-bundel), Nijmegen: Wolf Legal Publishers 2003, p. 475.

\section{De arresten van de Hoge Raad}

$\mathrm{Nu}$ op hoofdlijnen een beeld is geschetst van de gedragingen die in artikel $273 \mathrm{f}$ lid $1 \mathrm{Sr}$ als mensenhandel zijn strafbaar gesteld, is het zaak aandacht te besteden aan de arresten van de Hoge Raad. Als gezegd lag daarin telkens de vraag voor of 'uitbuiting' als impliciet bestanddeel van de aan de orde zijnde gedraging heeft te gelden. Het gaat dan om de subleden 3, 4, 5 en 9. Alleen ten aanzien van sublid 5, de enige van de vier gedragingen die uitsluitend op minderjarigen ziet, heeft de Hoge Raad de genoemde vraag ontkennend beantwoord. ${ }^{16}$ In het navolgende worden, zoals hierboven al aangekondigd, uitsluitend de arresten besproken waarin de Hoge Raad tot het inlezen van het uitbuitingsbestanddeel is gekomen. De bespreking zal steeds worden voorafgegaan door een beknopte behandeling van de wetshistorie van het betreffende sublid. De angehouden volgorde is chronologisch, wat maakt dat de bespreking een aanvang neemt bij de arresten die de Hoge Raad ten aanzien van het vierde sublid heeft gewezen. Steeds zal bij de behandeling van de arresten de vraag worden betrokken hoe de Hoge Raad al dan niet tot het inlezen van het uitbuitingsbestanddeel is gekomen en wat het inlezen daarvan impliceert voor de aard en reikwijdte van de besproken gedraging.

\subsection{Sublid 4}

In sublid 4 is strafbaar gesteld degene die een ander met een in sublid 1 genoemd middel dwingt of beweegt zich voor arbeid of diensten beschikbaar te stellen. De redactie van deze bepaling is ontleend aan artikel 250a lid 1 sublid 1 (oud) Sr, dat tot 1 januari 2005 in het Wetboek van Strafrecht was opgenomen. Daarin zag de gedraging nog niet op alle vormen van gedwongen arbeid of dienstverlening, maar uitsluitend op werkzaamheden in de seksuele sfeer. De uitbreiding naar andersoortige arbeid of diensten werd ingegeven door de implementatie van het VN-Mensenhandelprotocol, waarin staten wordt opgedragen om ook de mensenhandel buiten de seksindustrie strafbaar te stellen.

Als gezegd wordt de gedraging in sublid 4 in de memorie van toelichting afgezet tegen de gedraging die in sublid 1 is opgenomen. Gaat het bij laatstgenoemde gedraging om een handeling met het oogmerk van uitbuiting, in geval van sublid 4 is de gedraging de uitbuiting zelf. Met het oog op het vervolg is het belangrijk om op te merken dat de wetgever die uitbuiting niet als aansprakelijkheidsbeperkende voorwaarde heeft gedacht, althans dat is niet expliciet uit de wetsgeschiedenis af te leiden. Veeleer lijkt de wetgever een nadere omschrijving van deze gedraging te hebben willen geven, zonder daaraan consequenties te verbinden met betrekking tot het bewijs. Het zij herhaald dat deze gedraging eerder - in ongeveer dezelfde vorm - in

16. HR 2 oktober 2018, ECLI:NL:HR:2018:1823, NJ 2018/402 
artikel 250a lid 1 sublid 1 (oud) Sr had gestaan. De wetgever is zich in de memorie van toelichting ervan bewust dat sublid 4 ook op niet-seksuele vormen van uitbuiting zou gaan zien, maar verbindt hieraan niet de conclusie dat andere, bijvoorbeeld hogere, bewijsvereisten zouden moeten gelden. Reeds bij de inwerkingtreding van de verbrede bepaling werden daarbij vraagtekens geplaatst. Machielse wees erop dat ook zogenoemde 'eetpiraten' onder de bepaling zouden komen te vallen: personen die een maaltijd in een restaurant bestellen en consumeren, maar weglopen zonder de rekening te voldoen: is hier immers niet sprake van het door misleiding bewegen van mensen tot het verrichten van een dienst? ${ }^{17}$

In de feitenrechtspraak is inderdaad een aantal keren deze grammaticale uitleg gevolgd, vooral klemmend in de zaken waarin scholieren werden veroordeeld voor mensenhandel voor het door misleiding bewegen van medescholieren tot het afsluiten van telefoonabonnementen. ${ }^{18}$ Daarnaast waren er ook feitenrechters die anders oordeelden en 'uitbuiting' niet alleen als omschrijving, maar nadrukkelijk als bestanddeel van de sub 4-gedraging beschouwden. Ook in 2013 oordeelde Hof Den Haag langs die lijnen, in een zaak waarin de verdachte verschillende minder- en meerderjarigen tot een drugstransport had aangezet, onder meer door het middel 'misleiding'. Naar het oordeel van het hof is voor een bewezenverklaring van deze vorm van mensenhandel niet alleen vereist dat de wettelijke bestanddelen worden bewezen, maar moet ook sprake zijn van een 'veronderstelling van uitbuiting'. ${ }^{19}$ De Hoge Raad laat dat oordeel in stand. ${ }^{20}$ Een halfjaar later komt hij tot eenzelfde slotsom en overweegt de Hoge Raad expliciet dat het bestanddeel 'uitbuiting' in sublid 4 moet worden ingelezen. Vanwege het belang daarvan, ook voor de in paragraaf 3.2 en 3.3 nog te bespreken subleden, is de kernoverweging hier integraal opgenomen:

'Mede gelet op de wetsgeschiedenis en in aanmerking genomen dat handelen in strijd met art. 273f, eerste lid aanhef en onder $4^{\circ}$, Sr wordt gekwalificeerd als "mensenhandel" en wordt bedreigd met een gevangenisstraf van acht jaren, moet worden aangenomen dat de in het vierde onderdeel omschreven gedragingen alleen strafbaar zijn als zij zijn begaan onder omstandigheden waarbij uitbuiting kan worden verondersteld (vgl. HR 24 november 2015, ECLI:NL:HR: 2015:3309).

17. T.J. Noyon/G.E. Langemeijer/J. Remmelink, Het Wetboek van Strafrecht, voortgezet door J.W. Fokkens \& A.J.M. Machielse, zevende druk, Deventer: Wolters Kluwer, art. $273 \mathrm{f} \mathrm{Sr}$, aant. 6 (online, laatst bijgewerkt op 1 mei 2016)

18. Zie daarover L.B. Esser \& C.E. Dettmeijer-Vermeulen, 'Mensenhandel op een tweesprong. De omgang van rechters met de ruim geformuleerde mensenhandelgedraging in de delictsomschrijving van artikel $273 \mathrm{f} \mathrm{lid}$ 1 sub 4 Sr', DD 2014/48, afl. 7, p. 512-528.

19. Hof Den Haag 6 september 2013, ECLI:NL:GHDHA:2013:3398.

20. HR 24 november 2015, ECLI:NL:HR:2015:3309, NJ 2016/313 m.nt. P.H.P.H.M.C. van Kempen.
Dit brengt mee dat die gedragingen eerst dan als "mensenhandel" kunnen worden bestraft indien uit de bewijsvoering volgt dat voldaan is aan voormelde voorwaarde dat zij zijn begaan onder omstandigheden waarbij uitbuiting kan worden verondersteld. Het oordeel van het Hof dat "uitbuiting" moet worden aangemerkt als een impliciet bestanddeel van art. $273 \mathrm{f}$, eerste lid aanhef en onder $4^{\circ}, \mathrm{Sr}$, is derhalve juist.

Gelet op het vorenoverwogene heeft het Hof met juistheid geoordeeld dat voor bewezenverklaring van een op art. 273 f, eerste lid aanhef en onder $4^{\circ}$, Sr toegesneden tenlastelegging is vereist dat op grond van de omstandigheden van het geval uitbuiting komt vast te staan. Daarbij komt, gelet op hetgeen de Hoge Raad heeft overwogen en beslist in zijn arrest van 27 oktober 2009, ECLI:NL:HR:2009:BI7099, NJ 2010/598, onder meer betekenis toe aan de aard en duur van de tewerkstelling, de beperkingen die zij voor de betrokkene meebrengt en het economisch voordeel dat daarmee door de tewerksteller wordt behaald terwijl bij de weging van deze en andere relevante factoren de in de Nederlandse samenleving geldende maatstaven als referentiekader dienen te worden gehanteerd. Hierbij geldt in geval van minderjarige slachtoffers dat de beoordeling van dergelijke factoren tot een andere uitkomst kan leiden dan in het geval het slachtoffer meerderjarig is (vgl. HR 24 november 2015, ECLI:NL:HR:2015:3309). ${ }^{21}$

Zoals te zien, gebruikt de Hoge Raad een wetshistorische en wetssystematische interpretatiemethode, waarbij in vergelijking met zijn eerdere arrest opvalt dat in 2016 ook de strafbedreiging als systematisch argument wordt aangevoerd. Bovendien laat de Hoge Raad er, anders dan in zijn arrest uit 2015, geen misverstand over bestaan hoe het extra uitbuitingsvereiste moet worden begrepen: als bestanddeel van de delictsomschrijving die in sublid 4 is opgenomen. Zijn arrest uit 2015 liet dat in het midden: het vereiste dat het handelen in sublid 4 slechts strafbaar is als dat begaan is onder omstandigheden waarbij uitbuiting kan worden verondersteld, kan - zonder nadere toelichting - ook als een (buitenwettelijke) kwalificatieuitsluitingsgrond worden beschouwd. ${ }^{22}$

Tegen de achtergrond van de hierboven kort aan de orde gekomen totstandkomingsgeschiedenis kan aan de overwegingen van de Hoge Raad wel het een en ander worden afgedaan. Zo leidt de wetgeschiedenis minder dwingend tot de slotsom dat uitbuiting van sublid 4 een bestanddeel is dan de overwegingen van de Hoge Raad doen vermoeden; de wetgever omschrijft de gedraging weliswaar als primair op de uitbuiting gericht, maar zegt nergens dat dit ook als bestanddeel moet worden begrepen. Had hij dit begrip bestanddeel willen laten zijn, dan had het immers meer voor de hand gelegen als de

21. HR 5 april 2016, ECLI:NL:HR:2016:554, NJ 2016/315 m.nt. P.H.P.H.M.C. van Kempen.

22. Als zodanig wordt het ook begrepen door Machielse, in: Noyon/Langemeijer/Remmelink, art. $273 \mathrm{f} \mathrm{Sr,} \mathrm{aant.} 6$. 
wetgever dat als zodanig in de wet had opgenomen of daaraan in elk geval enige opmerkingen had gewijd.

Het systematische argument dat door de Hoge Raad wordt gebezigd is primair toegespitst op de kwalificatie van de gedraging in sublid 4 als 'mensenhandel'. De beargumentering lijkt te zijn dat uitbuiting bestanddeel is van deze gedraging omdat die als mensenhandel is gekwalificeerd. Van Kempen heeft er in zijn annotatie bij dit arrest terecht op gewezen dat het consequent doorvoeren van deze redenering impliceert dat uitbuiting - of een oogmerk daarop - van alle subleden in het eerste lid van artikel $273 \mathrm{f}$ een onderdeel moet zijn. ${ }^{23}$ Dat lijkt wel heel ver te gaan. Weliswaar kan met Van Kempen worden opgemerkt dat de kwalificatie 'mensenhandel' duidt op een 'ernstig onrecht', het inlezen van een extra bestanddeel zou idealiter op een wat scherper aanknopingspunt in de wetsgeschiedenis moeten zijn gebaseerd. Een benadering die de specifieke, op het sublid toegespitste wetsgeschiedenis tot uitgangspunt neemt, doet mijns inziens ook meer recht aan een benadering waarin de algemene kwalificatie 'mensenhandel' tot uitgangspunt wordt genomen. Bovendien kan dan meer recht worden gedaan aan de verschillen tussen de gedragingen die in het eerste lid zijn opgenomen.

Kijken we naar de implicaties van het inlezen van het uitbuitingsbestanddeel, dan is duidelijk dat dit in het kader van de eerste hoofdvraag uit het rechterlijk beslissingsmodel aan de orde dient te komen (art. $350 \mathrm{~Sv}$ ). De vraag rijst hoe het bestanddeel precies in de delictsomschrijving moet worden ingelezen. Die vraag is nog niet eenvoudig te beantwoorden. Dienen eerst alle wettelijke bestanddelen te worden bewezen vooraleer kan worden overgegaan tot de vraag of de optelsom van dit alles uitbuiting oplevert? Is dat inderdaad de te bewandelen route, dan fungeert het uitbuitingsbestanddeel alsnog als een soort kwalificatie-uitsluitingsgrond, die als het ware - in de woorden van Kelk en De Jong - de bewezenverklaarde feiten op de Typizität met uitbuiting toetst. ${ }^{24}$ Wat het typische aan uitbuiting is, is een vraag die in het eerste arrest niet wordt behandeld en die zich ook uit de vrije algemeen getoonzette wetshistorie niet laat afleiden. Het tweede arrest is wat dat betreft richtinggevender, omdat de Hoge Raad expliciteert dat bij die toetsing dezelfde maatstaven kunnen worden gehanteerd als bij het bewijs van het 'oogmerk van uitbuiting' in de zin van de subleden 1 en 2 . Bij de vraag of sprake is geweest van uitbuiting dient te worden gekeken naar de aard en duur van de verrichte werkzaamheden, de beperkingen die de tewerkstelling meebracht voor het slachtoffer en het door de tewerksteller behaalde economisch voordeel. Voorstelbaar is dat op de zitting eerst wordt bekeken of tot het bewijs van de wettelijke (ten laste gelegde) bestanddelen kan worden gekomen en dat het (tot dusverre) bewezenverklaarde daarna wordt bezien in het

23. Annotatie P.H.P.H.M.C. van Kempen, bij HR 5 april 2016, ECLI:NL:HR 2016:554, NJ 2016/315.

24. C. Kelk \& F. de Jong, Studieboek materieel strafrecht, Deventer: Wolters Kluwer 2016, p. 108. licht van de zojuist genoemde criteria. Het hangt dan van de bewezenverklaarde feiten af wat in concreto aan die uitbuitingscriteria wordt getoetst. Doorgaans zullen dat de daadwerkelijk voor een verdachte verrichte werkzaamheden zijn en de omstandigheden waaronder die plaatshadden. Het verdient echter herhaling dat de wettelijke bestanddelen niet vergen dat van die werkzaamheden sprake is geweest: het constitutief gevolg van dit delict is immers gelegen in het zich beschikbaar stellen daarvoor. Blijft het daarbij, dan ligt het zwaartepunt dus bij de vraag of dat beschikbaar stellen geschiedde onder omstandigheden die uitbuiting kunnen worden genoemd. Meer dan in de vervolgfase (het werken zelf) ligt dan vermoedelijk de nadruk op de aard van de dwangmiddelen waardoor personen zich voor de (niet-verrichte) arbeid of diensten hebben beschikbaar gesteld.

\subsection{Sublid 3}

In sublid 3 is kort gezegd als mensenhandel strafbaar gesteld degene die een ander aanwerft of medeneemt met het oogmerk om die ander in een ander land in de prostitutie te werk te stellen. ${ }^{25}$ De verbreding naar andersoortige dan seksuele werkzaamheden is aan dit sublid voorbijgegaan. Niettemin is de reikwijdte van dit sublid zeer ruim. Zo vormen 'uitbuiting' noch de voornoemde middelen bestanddelen van deze mensenhandelmodaliteit. Ook als een persoon uit het buitenland op vrijwillige basis beslist om in Nederland in de prostitutie te gaan werken, kan degene die hem of haar bij de overdracht naar hier behulpzaam is, strafbaar zijn aan mensenhandel. De handelingen 'aanwerven' en 'medenemen' zijn door de Hoge Raad bovendien al in eerdere arresten van een ruime, feitelijke uitleg voorzien. ${ }^{26}$

De strafbaarstelling van de in sublid 3 opgenomen gedraging is een uitvloeisel van een verplichting die is opgenomen in het Internationaal Verdrag van Genève van 1933 nopens de bestrijding van de handel in meerderjarige vrouwen, dat, hoewel oud, voor Nederland nog steeds geldend recht vormt. ${ }^{27}$ De ruime reikwijdte van deze gedraging leidde op meer momenten in het verleden tot discussie. Zo trachtte toenmalig Tweede Kamerlid Halsema (GroenLinks) in 1999, via een amendement, daarin het bestanddeel 'bedrieglijk' in te voegen, zodat toch een soort misleidingsbestanddeel daarvan onderdeel zou worden. ${ }^{28}$ Het wetsartikel zou daarmee ook meer congruent worden gemaakt aan de herziene uitgangspunten van het Nederlands prostitutiebeleid,

25. Daarnaast is ook nog de handeling 'ontvoeren' opgenomen. Anders dan bij de andere handelingen gaat het hier om een handeling die reeds van zichzelf wederrechtelijk is; het is geen handeling qua talis. De problematiek rondom de ruime formulering van de gedraging in sublid 3 is hier minder prangend en een bespreking van dit bestanddeel wordt dan ook achterwege gelaten, zeker nu dit bestanddeel in de rechtspraktijk een ondergeschikte rol speelt. Zie ook Esser 2019, p. 208.

26. Zie over 'aanwerven' HR 18 april 2000, ECLI:NL:HR:2000:ZD1788, NJ 2000/443, r.o. 3.3.3 en over 'medenemen' HR 20 december 2005, ECLI:NL:HR:2005:AU3425, NJ 2006/35, r.o. 3.5.

27. Het Internationaal Verdrag van Genève van 11 oktober 1933 nopens de bestrijding van de handel in meerderjarige vrouwen, Stb. 1935, 598.

28. Kamerstukken II 1998/99, 25437, 15. 
dat sinds 2000 met de opheffing van het 'bordeelverbod' immers uitgaat van de zelfbeschikking van de betrokken sekswerkers; een strafrechtelijke benadering is alleen dan geindiceerd indien sprake is van dwang of minderjarige slachtoffers. ${ }^{29}$ Het amendement kon echter op weinig steun rekenen en ook de regering wilde er niet aan. Opeenvolgende ministers hebben, ook later nog, de meerwaarde van de strafbaarstelling van sublid 3 benadrukt. $^{30}$

Dat laat onverlet dat vooral vanaf 2014 in de feitenrechtspraak discussie over de reikwijdte van sublid 3 begon te ontstaan. ${ }^{31}$ Die kan vooral worden verklaard vanuit het ongemak dat een als mensenhandel gekwalificeerde gedraging kan, moet, worden bewezenverklaard zonder dat de betrokken persoon tot het werk in de prostitutie is gedwongen of daarin is uitgebuit. ${ }^{32}$ De op het niveau van de feiteninstanties ontstane onzekerheid leidde tot een cassatieberoep in een zaak waarin de verdachte werd vervolgd voor het verrichten van hand- en spandiensten rondom de tewerkstelling van een prostituee uit Hongarije. Feitelijk kwam het erop neer dat zij voor de betrokken prostituee, die bij de politie verklaarde dat zij het werk uit vrije wil deed, een vliegticket had geregeld voor de vlucht van Hongarije naar de luchthaven van Eindhoven. Het door de verdachte ingestelde middel keert zich tegen het oordeel van het hof dat het bewezenverklaarde als mensenhandel kan worden aangemerkt. De Hoge Raad laat het middel slagen en overweegt:

'Mede gelet op de wetsgeschiedenis en in aanmerking genomen dat handelen in strijd met art. 273f, eerste lid aanhef en onder $3^{\circ}$, Sr wordt gekwalificeerd als "mensenhandel" en wordt bedreigd met een gevangenisstraf van acht jaren, moet worden aangenomen dat de in het derde onderdeel omschreven gedragingen alleen strafbaar zijn als zij zijn begaan onder omstandigheden waarbij uitbuiting kan worden verondersteld (vgl. HR 24 november 2015, ECLI:NL:HR: 2015:3309).

Dit brengt mee dat die gedragingen eerst dan als "mensenhandel" kunnen worden bestraft indien uit de bewijsvoering volgt dat voldaan is aan voormelde voorwaarde dat zij zijn begaan onder omstandigheden waarbij uitbuiting kan worden verondersteld. "Uitbuiting" moet worden aangemerkt als een impliciet bestanddeel van art. 273f, eerste lid aanhef en onder $3^{\circ}$, Sr (vgl. HR 5 april 2016, ECLI:NL:HR:2016:556

29. Zie ook Machielse, in: Noyon/Langemeijer/Remmelink, art. 273f, aant. 1 (online).

30. Esser 2019, §5.4

31. Zie daarover S.E. van den Brink, 'De ratio en reikwijdte van artikel $273 f$ lid 1 sub 3 Sr', TPWS 2013, afl. 1, p. 2-5.

32. Klip problematiseert de strafbaarstelling weer vooral met het oog op het Europese vrije verkeer van personen en diensten, zie A.H. Klip, annotatie bij HR 10 september 2013, ECLI:NL:HR:2013:670, NJ 2015/443. ten aanzien van het vierde onderdeel van art. 273f, eerste lid, Sr).' 33

Opvallend aan deze overwegingen is dat die precies hetzelfde luiden als de overwegingen ten aanzien van sublid 4, terwijl beide subleden een geheel andere achtergrond kennen. Daarnaast geldt dat de wetsgeschiedenis van sublid 3 geen aanwijzingen bevat dat de wetgever het toepassingsbereik van deze modaliteit van mensenhandel heeft willen beperken. Daaruit valt nu juist op te maken dat hij die ruime reikwijdte bewust heeft erkend en geaccepteerd. Ook blijkt niet, net als bij sublid 4, dat de wetgever de delictskwalificatie als een beperkende voorwaarde voor strafbaarheid heeft willen gebruiken.

Een ander prangend punt is natuurlijk hoe de uitleg van de Hoge Raad zich verhoudt tot de strafbaarstellingsverplichting uit het Verdrag van Genève van 1933. Het kost weinig moeite om te zien dat het verdrag door de uitleg van de Hoge Raad in feite buiten werking is gesteld. Dat is opmerkelijk, omdat dit verdrag voor Nederland nog steeds geldend recht vormt. Daarnaast kan ook hier, net als zojuist ten aanzien van sublid 4 al werd gedaan, de vraag worden opgeworpen wat het effect van de uitleg van de Hoge Raad is op de aard van het in sublid 3 opgenomen delict en de samenhang daarvan met de andere gedragingen die in het eerste lid van artikel $273 \mathrm{f} \mathrm{Sr}$ zijn opgenomen. Het ligt voor de hand ook hier de voornoemde criteria uit het Chinese horecaarrest een rol te laten spelen. De vraag is echter wanneer deze criteria precies moeten worden aangewend, mat, melke feitelijke situatie, met andere woorden aan deze criteria kan worden getoetst. Het lijkt vreemd om hier de feitelijke prostitutiewerkzaamheden tot uitgangspunt te nemen, nu sublid 3 immers in het bijzonder de aanwerving daarvoor of het medenemen met dat oogmerk uitlicht, het is een formeel omschreven delict. Logischer is het om de omstandigheden waaronder het aanwerven of medenemen plaatsvond langs de lat van de uitbuitingscriteria te leggen. Maar is het juist dit handelen dat moet worden uitgelicht, dan is moeilijk nog te zien welke meerwaarde de strafbaarstelling van deze gedraging heeft naast die van sublid 1 , waarbij het als gezegd gaat om het werven met een oogmerk van uitbuiting: zit er feitelijk nu zo'n groot verschil tussen het aanwerven onder omstandigheden die uitbuiting kunnen worden genoemd en het werven met het oogmerk van uitbuiting? En rechtvaardigt een dergelijk verschil aparte strafbaarstelling?

\subsection{Sublid 9}

Karakteristiek aan de gedraging die in het negende sublid is opgenomen is dat het door de mensenhandelaar te hanteren middel niet ziet op het bewerkstelligen van het sekswerk zelf, maar is gericht op het afstaan van door sekswerk verkregen opbrengsten. De persoon die

33. HR 17 mei 2016, ECLI:NL:HR:2016:857, NJ 2016/314 m.nt P.H.P.H.M.C. van Kempen. Herhaald in HR 20 december 2016, ECLI:NL:HR:2016:2909, NJ 2017/16; HR 20 december 2016, ECLI:NL:HR:2016:2928; HR 16 mei 2017, ECLI:NL:HR:2017:884. 
een andere persoon tot het afstaan van inkomsten uit diens verrichte prostitutiewerk dwingt of beweegt, is ook strafbaar indien dit werk door de sekswerker vrijwillig werd gedaan. ${ }^{34}$ Het betreft hier als gezegd een kenmerkend onderscheid met de andere voordeeltrekkersbepalingen, waarin het wederrechtelijke profiteren steeds ook wordt voorafgegaan door een strafbare gedraging. ${ }^{35}$

Bij de opheffing van het algemeen bordeelverbod, in 2000, was de souteneursgedraging uit sublid 9 bijna gedecriminaliseerd. Door de inbreng van de PvdA stelde minister Sorgdrager van Justitie (D66) zich uiteindelijk de vraag of het '(...) denkbaar [is] dat er sprake is van een situatie waarbij een prostituee wordt gedwongen tot de afgifte van de opbrengst van seksuele handelingen zonder dat er sprake is van onvrijwillige prostitutie'. ${ }^{36}$ Uiteindelijk acht de minister die situatie 'niet uitgesloten' en stelt zij de strafbaarstelling van onvrijwillige afdracht van uit (vrijwillige) prostitutie afkomstige gelden alsnog, bij nota van wijziging, voor. ${ }^{37}$

In de zaak die leidde tot het te bespreken arrest ging het om een Roemeense prostituee die al enige jaren vrijwillig in de prostitutie werkzaam was. De verdachte, ook afkomstig uit Roemenie, was haar vriend. De vrouw leerde hem kennen toen ze reeds als prostituee werkzaam was. Hij had verder weinig bemoeienis met haar werk, anders dan dat in het arrest van Hof Amsterdam melding wordt gemaakt van het feit dat hij op een gegeven moment een andere chauffeur voor haar regelde. Wel stond de vrouw flinke bedragen aan de verdachte af; zij stortte eens $€ 10.500$ op zijn rekening en op een ander moment maakte zij $€ 15.850$ over naar de zus van de verdachte. ${ }^{38}$ Ten aanzien van het tenlastegelegde sublid 9 komt het hof tot de vaststelling dat sprake is geweest van het door misleiding bewegen van de prostituee om haar opbrengsten uit sekswerk af te staan. De misleiding bestond volgens het hof eruit dat de verdachte telefonisch had gezegd dat hij het geld nodig had '(...) voor doeleinden, het bestaan waarvan hij achteraf bij de politie heeft ontkend en die dus kennelijk door hem waren verzonnen'. ${ }^{39}$ De verdachte heeft dan ook, aldus het hof, 'doelbewust een foute voorstelling van zaken gegeven over zijn financiële problemen'. Hoewel het bewijs van het door misleiding bewegen tot het afstaan van de opbrengsten taalkundig gezien in elk geval volstaat voor een bewezenverklaring, leest het hof in de delictsomschrijving ook '(het oogmerk van) uitbui-

34. Zie ook Concl. A-G Bleichrodt 24 april 2018, ECLI:NL:PHR:2018:394, punt 18.

35. Namelijk een andere, in sublid 1 opgenomen mensenhandelgedraging. Een uitzondering geldt mogelijk voor sublid 6, nu daarin het opzettelijk voordeeltrekken uit uitbuiting is strafbaar gesteld, maar uitbuiting als zodanig niet is strafbaar gesteld. Zie hierover ook K. Lindenberg, Prostituant en strafrecht. Quickscan van de strafrechtelijke verantwoordelijkheden van de prostituant bij mensenhandel en minderiarigheid, Zutphen: Uitgeverij Paris 2014, p. 40-41.

36. Kamerstukken II 1997/98, 25437, 4, p. 14.

37. Kamerstukken II 1997/98, 25437, 5-6.

38. Het hof gaat ervan uit dat de verdachte in elk geval een deel van dit geld zelf heeft ontvangen.

39. Hof Amsterdam 8 december 2016, ECLI:NL:GHAMS:2016:5236. ting' in en komt het tot de slotsom dat de verdachte weliswaar 'op schaamteloze wijze' van de Roemeense vrouw heeft geprofiteerd, maar dat '(...) niet kan worden gezegd dat zijn handelen als noodzakelijk en door hem gewild gevolg heeft meegebracht dat [betrokkene 1] door hem werd of zou worden uitgebuit'. ${ }^{40}$

In cassatie wordt opgekomen tegen deze restrictieve uitleg. De Hoge Raad laat het middel evenwel falen en overweegt dat ook in dit sublid het uitbuitingsbestanddeel moet worden ingelezen. Naast een algemene verwijzing naar de wetsgeschiedenis, de delictskwalificatie en de strafbedreiging - de overwegingen die we kennen uit de arresten ten aanzien van subleden 3 en 4 - overweegt de Hoge Raad ten aanzien van dit sublid in het bijzonder:

'Dat art. 250a, eerste lid aanhef en onder $6^{\circ}, \mathrm{Sr}$ (welke bepaling de voorganger is van art. $273 \mathrm{f}$, eerste lid aanhef en onder $9^{\circ}, \mathrm{Sr}$ ) blijkens de geschiedenis van de totstandkoming van die bepaling zoals weergegeven in de conclusie van de Advocaat-Generaal onder 8, ertoe strekte ook het profiteren van vrijwillige - en dus niet als "uitbuiting" aan te merken prostitutie tegen te gaan, leidt niet tot een ander oordeel [dan dat uitbuiting bestanddeel is van dit sublid, LE], mede in aanmerking genomen dat de opsomming van strafbare gedragingen en "middelen" in art. $250 \mathrm{a}$, eerste lid aanhef en onder $6^{\circ}, \mathrm{Sr}$ beduidend beperkter is dan die in art. 273f, eerste lid aanhef en onder $9^{\circ}$ in samenhang met art. 273f, eerste lid aanhef en onder $1^{\circ}$, Sr. $^{41}$

De Hoge Raad komt in het arrest op dezelfde wijze tot het inlezen van het uitbuitingsbestanddeel, maar voegt daar nog wel enige, op de gedraging in sublid 9 toegespitste overwegingen aan toe. Naast de typering van sublid 9 als vorm van seksuele uitbuiting, noemt de Hoge Raad ook dat het aantal middelen dat in sublid 9 is opgenomen door de wijziging van de redactie van deze bepaling in 2005 is toegenomen. Het is moeilijk precies te achterhalen welke betekenis de Hoge Raad hieraan precies verleent. Een mogelijke redenering zou kunnen zijn dat de uitbreiding van de strafrechtelijke aansprakelijkheid die werd gerealiseerd door het invoeren van nieuwe middelen, toch enig tegenwicht moet worden geboden. ${ }^{42}$ Lestrade merkt in haar annotatie nog op dat in 2005 niet alleen het door een middel dwingen,

40. Hof Amsterdam 8 december 2016, ECLI:NL:GHAMS:2016:5236.

41. HR 16 oktober 2018, ECLI:NL:HR:2018:1941, NJ 2019/272 m.nt. N. Rozemond. Herhaald in HR 25 juni 2019, ECLI:NL:HR:2019:1026.

42. Zo ook annotator Rozemond, die opmerkt: 'De ruimere strekking van art. 250a lid 1 onder $6^{\circ} \mathrm{Sr}$ (ook het tegengaan van het profiteren van vrijwillige prostitutie) werd beperkt door de opsomming van gedragingen en middelen. In art. $273 \mathrm{flid} 1$ onder $1^{\circ}$ en $9^{\circ} \mathrm{Sr}$ is die opsomming ruimer en daarom moet het bereik van deze strafbepalingen worden beperkt door het impliciete bestanddeel uitbuiting.' Overigens ben ik het niet eens met zijn stelling dat sublid 9 'niet de strekking heeft om het profiteren van vrijwillige prostitutie tegen te gaan'. Op basis van de wetsgeschiedenis heeft het die strekking nu juist wel. Annotatie N. Rozemond, bij HR 16 oktober 2018, ECLI:NL:HR:2018:1941, NJ 2019/272. 
maar ook het door een middel bemegen strafbaar werd, maar net als haar meen ik dat daaruit moeilijk een argument kan worden ontleend voor het inlezen van een uitbuitingsbestanddeel, ${ }^{43}$ temeer daar de wetgever met het aanbrengen van het onderscheid tussen dmingen en bemegen geen verschil in strafwaardigheid beoogde uit te drukken, maar vooral dat de vrijwilligheid van mensen op zeer uiteenlopende wijzen teniet kan worden gedaan. ${ }^{44}$ Los van deze kanttekeningen geldt dat het opmerkelijk is hoezeer in het arrest een beroep wordt gedaan op de wetsgeschiedenis, terwijl daarin nu juist geen aanknopingspunten te vinden zijn voor een restrictieve uitleg van deze bepaling. Veelzeggend is het dat A$\mathrm{G}$ Bleichrodt in zijn conclusie voor dit arrest juist op basis van de wetsgeschiedenis tot de slotsom komt dat 'uitbuiting' niet als bestanddeel in sublid 9 moet worden ingelezen. ${ }^{45}$ Volgens hem heeft de wetgever de strafbaarheid van gedwongen afdracht uit vrijmillige prostitutie 'nadrukkelijk onder ogen gezien en aanvaard'. ${ }^{46}$

Los van de wijze waarop de Hoge Raad tot zijn oordeel komt, is het ook nu weer de vraag waar precies het uitbuitingsbestanddeel in de tekst van de delictsomschrijving moet worden ingelezen en welke implicaties dat heeft. Uit zijn overweging met betrekking tot artikel 250a lid 1 sublid 6 (oud) Sr zou kunnen worden afgeleid dat het steeds moet gaan om het voordeeltrekken uit gedwongen prostitutie (de uitbuiting zelf, volgens de Hoge Raad), maar wordt die lezing gevolgd dan is niet duidelijk wat de meerwaarde van sublid 9 naast het huidige sublid 6 nog is, waarin immers precies die gedraging is strafbaar gesteld. Volgen we de wettelijke omschrijving van de gedraging dan dient hier toch vooral te worden bezien in hoeverre de Chinese horeca-criteria kunnen worden toegepast op de wijze waarop de een de ander met een middel dwingt dan wel beweegt hem uit opbrengsten uit prostitutiewerk te bevoordelen. Voorstelbaar is dan dat de aard-en duur-criteria hier niet worden toegepast op de werkzaamheden zelf, maar op de wijze waarop de verdachte de opbrengsten van het slachtoffer heeft weten te ontfutselen. Bij die beoordeling kan bijvoorbeeld worden betrokken de aard van het door de verdachte gehanteerde middel en de duur of frequentie waarmee dat is aangewend. Dan kan vervolgens ook worden bezien in hoeverre de hantering daarvan beperkingen meebracht voor het slachtoffer; was de situatie voor het slachtoffer dusdanig bedreigend dat hij in redelijkheid niet anders kon dan de opbrengsten aan de verdachte afstaan? Het economisch voordeel-criterium kan in het kader van het bewijs worden toegespitst op de opbrengsten die aan de verdachte zijn of moesten worden afgestaan. Vanuit het uitbuitingsvereiste gedacht is het logisch als die opbrengsten niet tot kleine

43. Annotatie S.M.A. Lestrade, bij HR 16 oktober 2018, ECLI:NL:HR: 2018:1941, SR Updates 2018-0397, r.o. 7.

44. Zie daarover Esser 2019, p. 117. Veeleer drukte de wetgever hiermee uit dat de vrijwilligheid van mensen op zeer uiteenlopende wijzen teniet kan worden gedaan.

45. Zie Concl. A-G Bleichrodt 24 april 2018, ECLI:NL:PHR:2018:394, punt 21.

46. Concl. A-G Bleichrodt 24 april 2018, ECLI:NL:PHR:2018:394, punt 18. bedragen zijn beperkt. Tegelijkertijd, daar wees A-G Knigge al op in zijn conclusie voor het Chinese horecaarrest, ${ }^{47}$ is het vooral ook van belang dat genoemde criteria niet afzonderlijk, maar toch vooral in samenhang met elkaar worden bezien: zijn de opbrengsten relatief laag, dan kan alsnog van uitbuiting sprake zijn als geweld is toegepast. En andersom: ook indien een relatief lichtere vorm van dwang is aangewend - bijvoorbeeld misleiding - kan sprake zijn van uitbuiting als de verdachte in grote mate heeft geprofiteerd.

\section{Tussenconclusie: implicaties van het uitbuitingsbestanddeel}

$\mathrm{Nu}$ de arresten van de Hoge Raad zijn besproken, kan antwoord worden gegeven op de eerste vraag die in dit artikel centraal stond, namelijk die naar de implicaties van het inlezen van een uitbuitingsbestanddeel in de subleden 3, 4 en 9 van artikel $273 \mathrm{f}$ lid $1 \mathrm{Sr}$. Het moge op basis van het voorgaande duidelijk zijn dat de reikwijdte van het mensenhandelartikel daarmee in aanzienlijke mate is ingeperkt: waar voorheen voor een bewezenverklaring van deze delicten het bewijs van de wettelijke bestanddelen volstond, is nu ook vereist dat 'uitbuiting' wordt bewezen. Dit door de Hoge Raad ingelezen bestanddeel legt bovendien de lat niet licht hoger: feitelijk is het uitbuitingsbestanddeel van zowel de gedragingen in de subleden 3,4 als 9 het centrale onderdeel geworden en zal de rechter zich thans en in de toekomst vooral op het bewijs van juist dit (impliciete) bestanddeel moeten focussen. Tevens kan worden gezegd dat de delicten uit de betreffende subleden door het inlezen van het bestanddeel een ander strafrechtelijk verwijt zijn gaan uitdrukken, een verwijt dat deels in de wettekst zichtbaar is, maar waarvan de precieze strekking pas goed kan worden ontsloten als het in de jurisprudentie ontwikkelde uitbuitingsbestanddeel wordt betrokken.

Tegelijkertijd bestaat momenteel nog onzekerheid over de precieze invloed van het uitbuitingsbestanddeel in de subleden 3, 4 en 9. Hoewel hierboven enige opmerkingen zijn gewijd aan de mogelijke uitwerking daarvan, laat zich dit bestanddeel - in het bijzonder als daarbij de Chinese horeca-criteria worden betrokken - niet altijd eenvoudig inlezen. Fungeert het bij sublid 3 in feite als een oogmerk van uitbuiting? Of speelt het uitbuitingsbestanddeel veel meer een rol bij de vraag naar de wijze waarop een sekswerker is angeworven of medegenomen? En waarop dient bij het bewijs van het uitbuitingsbestanddeel te worden gelet als de verdachte wordt verweten een sekswerker te hebben gedwongen diens opbrengsten uit legaal sekswerk af te staan (sublid 9)? Moet dan de prostitutie zelf tóch onder uitbuitingsom- 
standigheden hebben plaatsgevonden? Of moet de mijze maarop de afdracht van inkomsten plaatsvond bij het bewijs centraal staan? Het zijn vragen waarop de rechtspraak van de Hoge Raad geen antwoorden verschaft.

Die onduidelijkheid werkt niet alleen door op het niveau van de subleden zelf, maar heeft ook gevolgen voor de samenhang tussen de gedragingen in artikel $273 \mathrm{f}$ lid 1 Sr. Ook zonder de implicaties van het inlezen van het uitbuitingsbestanddeel precies te doorgronden, kan worden vastgesteld dat moeilijk is in te zien welke meerwaarde de strafbaarstelling van de in sublid 3 opgenomen gedraging nog heeft naast die van sublid 1 . Hetzelfde geldt voor de wijze waarop de Hoge Raad sublid 9 heeft uitgelegd: de specifieke betekenis van dit sublid naast sublid 6 is, zo kan veilig worden gezegd, min of meer uitgehold. En zelfs kan de vraag worden gesteld of aparte strafbaarstelling van de gedraging in sublid 4 wel nodig is nu de criminalisering van die gedraging lijkt te worden ondervangen door de strafbaarstelling van de gedraging in sublid 1. Nu dit laatste (formeel omschreven) delict vaak vanuit zijn gevolgen wordt bewezen vergelijk de Chinese horeca-criteria - is het nog niet eenvoudig om onder woorden te brengen waarom het nodig is om een aparte strafbaarstelling te hebben voor degene die een ander door een middel dwingt dan wel beweegt tot het zich beschikbaar stellen voor arbeid of diensten (sublid 4), vooral nu dat door de Hoge Raad restrictief is uitgelegd.

Als het gaat om de implicaties van het inlezen van het bestanddeel 'uitbuiting' in de subleden 3, 4 en 9 zijn dus grosso modo twee belangrijke gevolgen te onderscheiden. Het eerste gevolg ligt op het niveau van de gedragingen zelf: de reikwijdte daarvan is in belangrijke mate ingeperkt. Het tweede gevolg ligt op het niveau van de strafbaarstelling van mensenhandel als geheel: het onderscheidend vermogen van sommige gedragingen is door de arresten duidelijk afgenomen, zelfs in die mate dat de vraag kan worden gesteld of de subleden 3 en 9, misschien zelfs 4, nog langer aparte strafbaarstelling behoeven. Ik zal me daarover niet verder uitlaten, maar dat uit de geschetste stand van zaken een opdracht aan de wetgever lijkt voort te vloeien, is overbodig om op te merken.

Tot slot nog enkele opmerkingen over de strafprocessuele implicaties van het inlezen van een uitbuitingsbestanddeel. Dat 'uitbuiting' een bestanddeel is van de genoemde subleden, betekent natuurlijk ook dat van een verdenking minder snel sprake zal zijn en dat voor het hanteren van strafvorderlijke bevoegdheden de drempel dus hoger is komen te liggen. Bovendien kan nog de lastige vraag worden opgeworpen welke gevolgen het uitbuitingsbestanddeel zou moeten hebben voor het ten laste leggen van de besproken subleden. Dat het gaat om een impliciet bestanddeel maakt dat het strikt genomen niet in de tenlastelegging behoeft te worden opgenomen of feitelijk behoeft te worden uitgewerkt. De vraag rijst wel hoe zuiver dat is, gelet op het feit dat het uitbuitingsbestanddeel tot de kern van de betreffende delicten is gaan horen. ${ }^{48}$ Het behoeft geen betoog dat het weglaten van dit bestanddeel, en de feitelijke uitwerking daarvan, uit de tenlastelegging, onwenselijk is gelet op de rechtszekerheid en de functies die aan de dagvaarding verbonden zijn. ${ }^{49}$

\section{Waardering}

Hoe kan de in deze bijdrage geschetste stand van zaken worden gewaardeerd specifiek bezien in het licht van de notie van rechtszekerheid en de scheiding der machten? Deze vraag is relevant om te stellen omdat de Hoge Raad met het inlezen van het uitbuitingsbestanddeel toch belangrijk rechtsvormend werk heeft verricht, dat direct de omvang van de strafrechtelijke aansprakelijkheid raakt. Tegen de achtergrond van de onzekerheid die in de feitenrechtspraak omtrent de reikwijdte van onderdelen van artikel $273 \mathrm{f}$ lid $1 \mathrm{Sr}$ was ontstaan, kan het zoeken naar afbakening door de Hoge Raad op zichzelf positief worden gewaardeerd. Niettemin zijn er toch zeker ook kanttekeningen te plaatsen bij de wijze waarop dat is gebeurd en de gevolgen die dat heeft gehad.

Ten aanzien van laatstgenoemde gevolgen springt in het oog dat het eerste lid van artikel $273 \mathrm{f}$ al met al nauwelijks meer als een goede afspiegeling kan worden beschouwd van hetgeen als mensenhandel strafbaar is gesteld in Nederland. Aan belangrijke subleden is een jurisprudentieel bestanddeel toegevoegd, dat dus in de wet niet zichtbaar is. Daartegen kan natuurlijk worden ingebracht dat voor veel, zo niet alle bestanddelen in delictsomschrijvingen geldt dat hun volle betekenis pas echt duidelijk wordt als de arresten van de Hoge Raad worden betrokken. Toch gaat het hier in mijn optiek om iets wezenlijk anders: in een niet gering aantal subleden is een bestanddeel toegevoegd dat bovendien een doorslaggevende betekenis speelt bij het bewijs. Dat dit onderdeel ondanks zijn relevantie niet zichtbaar is in de wet, makt dat de rechtszekerheid die aan dit artikel kan worden ontleend nogal is uitgehold en zoals te zien is geweest werkt dit niet alleen in het materieel, maar ook in het formeel strafrecht door.

De mijze maarop de Hoge Raad het mensenhandelartikel heeft afgebakend levert vooral spanning op in de relatie met de strafwetgever. Ten eerste kan in dit kader de vraag worden opgeworpen of de gekozen techniek - die van het inlezen van een bestanddeel - er één is die in het streven naar machtsevenwicht wel zo gelukkig is. Dient

48. Zie in dit verband bijvoorbeeld Keulen en Knigge, die opmerken dat wetstermen die tot de kern van een delict behoren doorgaans concretisering in de tenlastelegging behoeven. B.F. Keulen \& G. Knigge, Strafprocesrecht, Deventer: Wolters Kluwer 2016, p. 420.

49. Ik doel dan met name op de 'dubbele verwijzingsfunctie': de tenlastelegging moet aan de verdachte duidelijk maken welk historisch gebeuren hem wordt verweten en op welke delictsomschrijving precies de beschuldiging is gebaseerd. Vgl. G.J.M. Corstens, M.J. Borgers \& T. Kooijmans, Het Nederlands strafprocesrecht, Deventer: Wolters Kluwer 2018, p. 660 
het toevoegen van elementaire bestanddelen niet voorbehouden te zijn aan de wetgevende macht? En verschilt een dergelijke methodiek niet wezenlijk van het interpreteren van bestaande, door de wetgever aangereikte, dus wettelijke bestanddelen? Ik ben geneigd beide vragen bevestigend te beantwoorden, hoezeer wellicht ook zo'n benadering op het eerste gezicht een nogal legistische indruk maakt. Misschien was dit oordeel ook wel anders geweest als de wetgever in het verleden op meer geprononceerde wijze uitdrukking had gegeven aan zijn wens om het mensenhandelartikel vooral over de band van het uitbuitingsbestanddeel te beschouwen en af te bakenen. In het geval van de subleden 3 en 9 is nu juist sprake geweest van het tegendeel: in de wetsgeschiedenis zijn geen of weinig argumenten te vinden die erop wijzen dat de wetgever met deze bepalingen iets anders voor ogen had dan de wettekst van de betreffende subleden indiceert. In het geval van sublid 3 heeft de wetgever juist bewust gekozen voor een ruime strafbaarstelling, niet in de laatste plaats omdat die ook wordt voorgeschreven door een verdrag waaraan Nederland nog steeds gebonden is. En voor sublid 9 geldt zo'n internationale achtergrond weliswaar niet, maar is uit de wetshistorische stukken wel weer klip en klaar op te maken dat de wetgever dat zeker niet heeft willen reserveren voor situaties waarin sprake is van uitbuiting. Niet voor niets concludeert A-G Bleichrodt in zijn conclusie voor dit arrest dat de kritiek op de reikwijdte van dit sublid ' $(\ldots)$ vooral de rechtspolitieke afweging in het wetgevingstraject [raakt] $\cdot{ }^{50}$ Ook naar mijn mening is de afbakening ook in het geval van dit sublid primair een kwestie voor de wetgever.

\section{Conclusie}

Het rechtsvormende werk van de Hoge Raad in de afgelopen vier jaar heeft belangrijke implicaties gehad voor de reikwijdte van het mensenhandeldelict, hoewel over verschillende aspecten daarvan nog onduidelijkheid bestaat. Ook los daarvan kunnen in het licht van de notie van rechtszekerheid en de machtenscheiding belangrijke kanttekeningen worden geplaatst bij de wijze waarop de reikwijdte van het delict is afgebakend en de gevolgen die dit zowel in materieel- als formeelstrafrechtelijke zin heeft gehad. Tegen de achtergrond van de onduidelijkheden die in de feitenrechtspraak waren gerezen over de uitleg van onderdelen daarvan, kan zonder meer positief worden gewaardeerd dat de Hoge Raad binnen de strafbaarstelling van mensenhandel op zoek is gegaan naar een nieuw evenwicht. Zijn arresten van de afgelopen jaren dienen mijns inziens echter niet alleen op zichzelf te worden bezien, maar vooral ook te worden beschouwd als een vorm van communicatie met de wetgever: zij vormen een uitnodiging om de strafbaarstelling van mensenhandel opnieuw te doordenken. Tot een reactie van de wetgever, tot interactie, hebben de arres- ten nog niet geleid, maar in het bovenstaande is te zien geweest dat daartoe inmiddels aanleiding en noodzaak bestaat. 